\title{
Anti-Diarrhoeic and antibacterial Effects of Aqueous Pod Extract of Acacia nilotica in Albino Rats
}

\author{
UMARU $^{1 \mathrm{ia} *}$, B., ONYIYILI, P.A AND SAKA². S.
}

\begin{abstract}
${ }^{2}$ Department of Veterinary Biochemistry, Physiology and Pharmacology, University of Maiduguri, P.M.B 1069. Maiduguri, Nigeria. ${ }^{\text {a }}$ School of Health Sciences,Department of Pharmacy, Laboratory of Molecular Pharmacology, University Campus, Rio. Patra 265 04, Greece *Correspondence : bukamar@yahoo.co.uk, +306998208873
\end{abstract}

\section{SUMMARY}

The anti-diarrhoea effect of aqueous pod extract of Acacia nilotica was investigated in rats. The pod extract of $A$. nilotica was obtained by Soxhlet extraction using distilled water as a solvent and subjected to phytochemical screening. The result of phytochemical screening revealed the presence of saponins, tannins, alkaloids, cardiac glycosides, flavonoids, and reducing sugars. The elemental analysis of the extract revealed high concentration of sodium followed by magnesium, iron, cadmium, zinc, manganese and potassium. The aqueous extract significantly $(\mathbb{P}<0.05)$ reduced the number of unformed faeces in castor oil induced diarrhoea in rats. It also significantly $(P<0.05)$ reduced the gastrointestinal transit of activated charcoal. Enteropooling in the experimental rats was significantly $(P<0.05)$ reduced.

The in vitro antibacterial and fungal study showed that the extract inhibited the growth of Staphylococcus aureus, Proteus vulgaris, Shigella dysentery, E. coli, Streptococcus pyogenes, Pseudomonas aerogenosa, Salmonella typhi, and Bacillus albus, as well as Candida albicans. The aqueous pod extract was therefore found to possess active antdiarrhoeic, antibacterial and mycostatic ingredients.

KEY WORDS: Anti-diarrhoea, A. nilotica aqueous pod extract, antibacteria, Mycostatic.

\section{INTRODUCTION}

Acacia nilotica belong to member of the Family Fabaceae. Its tender branches are used as fodder for goats and sheep; stem bark crude extract is used to treat toothache, while the pods and leaves are useful in management of stomach ailments, skin disorders and diarrhoea (Duke, 1983). Acacia nilotica inner bark contain tannin $(18-23 \%)$ used for tanning and dying of leather, (National Academy of Science, 1980). Tender pods and shoots are used as vegetables and is fed to camels, sheep and goats especially in Sudan, where it is used to improve milk yield in these animals. In South Africa, the Zulus use the stem bark extract in treating cough, and the Chipi use the root bark in managing cases of tuberculosis, while the Masai use the stem bark and root decoction, to alleviate mood. In Ayurvedic medicine, the stem bark has been used for management of premature ejaculation (Pande et al., 1981). In north eastern Nigeria herbs from decoction of the pod of Acacia nilotica have been used in folk medicine for the control of diarrhoea, but has not been scientifically evaluated for it's efficacy and toxicity. Therefore this study was design to investigate it efficacy as anti-diarrhoeic and antibacterial agent.

\section{MATERIALS AND METHODS}

\section{Plant Collection, Identification and Extract Preparation}

Fresh pods and leaves of Acacia nilotica were collected from Lai-Lai grazing reserve, Potiskum Local Government Area of Yobe State and identified by a Plant Taxonomist at the Department of Biology University of Maiduguri. Voucher specimen was deposited at the Department of Veterinary Physiology and Pharmacology herbarium, University of Maiduguri, Nigeria.

The pods were air dried at room temperature for three weeks. Crushing of the pods was done in the laboratory using pestle and mortar, after which it was ground into powder. About two hundred grammes (200 gm) of the powdered pod was weighed and introduced into a conical flask and 1 litre of distilled water was added thereafter. The mixtures was then shaken and allowed to stand for 30 minutes, after which it was boiled for one hour, cooled and shaken vigorously, before filtration using whatman No. 1 filter paper. The filtrate was concentrated in a 
rotatory evaporator and stored at $4{ }^{\circ} \mathrm{C}$ until used, and the yield was $6.75 \%(\mathrm{w} / \mathrm{w})$.

\section{EXPERIMENTALANIMALS}

Wister albino rats of both sexes and weight were used for this experiment. They were kept in plastic cages and allowed a 2-3 week period of acclimatization before the commencement of the experiment. The experimental rats were fed with grower mash and drinking water ad libitum.

\section{Phytochemical Screening}

The aqueous pod extract was subjected to phytochemical screening for the identification of various classes of chemical compounds such as sterol, triterpenes, alkaloid, flavonoid, carbohydrates, tannins, emodols, anthracenosides, saponin and polyuronides using the method of Harborne (1975), Ioan (1976), Trease and Evans (1989) and Sofowora (1993).

\section{Determination of the Elemental Content}

Acacia nilotica pod powder was screened for elemental constituents using the technique described by Bhatia, (2005).

\section{Trace Elemental Content}

About $5 \mathrm{gm}$ of air dried sample in an evaporating dish was placed in an oven at $80^{\circ} \mathrm{C}$ and dried to a constant weight. The sample was placed in a weighed crucible and ashed at $500^{\circ} \mathrm{C}$ in hotspot furnance for three hours and screened for elemental constituents according to the method of Bhatia (2005).

\section{Effect of the aqueous extract on castor oil induced diarrhoea in rats}

Twenty five rats weighing between 120-190 gm were used for this study. The method of Offia and Chikwendu (1999) was used. The rats were deprived of feed 12 hours before the commencement of the experiment, but were allowed free access to water. They were divided into 5 groups of five rats each. Rats in groups A, $\mathrm{B}$, C received $250 \mathrm{mg} / \mathrm{kg}, 500 \mathrm{mg} / \mathrm{kg}$, and 750 $\mathrm{mg} / \mathrm{kg}$ dose of aqueous pod extract of Acacia nilotica orally respectively. Those in group D received $(2 \mathrm{ml})$ of normal saline orally, while those in group E were given diphenoxylate HCL 5 $\mathrm{mg} / \mathrm{kg}$ body weight intraperitonealy (I.P). The rats were housed singly in a cage lined with white blotting paper. One hour after extract treatment, the rats were each given $1 \mathrm{ml}$ of castor oil orally. The rats were observed for 6 hours for watery (wet) or unformed faeces. The unformed faeces from each rat were counted at the end of the experiment and a group mean obtained.

\section{Effect of aqueous extract on gastrointestinal transit of activated charcoal}

Twenty five rats weighing between 130-198 gm were also used for this experiment. The method of Chitme et al. (2004) was used. The animals were deprived of feed 18 hours to the experiment, and thereafter divided into 5 groups of 5 rats each. The rats were allowed free access to water. Group 1 received $(2 \mathrm{ml})$ of normal saline orally and Group 2 received intraperitonealy (I.P) $3 \mathrm{mg} / \mathrm{kg}$ of atropine sulphate. Groups 3, 4 and 5 were treated orally with $250 \mathrm{mg} / \mathrm{kg}, 500 \mathrm{mg} / \mathrm{kg}$ and $750 \mathrm{mg} / \mathrm{kg}$ doses of aqueous pod extract of Acacia nilotica respectively. Ten minutes after drug and extract administration $1 \mathrm{ml}$ of $5 \%$ activated charcoal suspension in $10 \%$ aqueous solution of Acacia powder was given orally to each rat. The rats were sacrifice 30 minutes later and the abdomen opened. The distance travelled by charcoal meal from pylorus was measured and expressed as percentage of the total length of the intestine from pylorus to the caecum (Mascolo et al., 1999).

\section{Effect of aqueous extract on castor oil induced enteropooling}

Twenty five rats weighing between 110-200 gm were used. The intra-luminal fluid accumulated was determined by the method of Robert et al. (1976). The rats were fasted overnight and separated into five groups of 5 rats each. Group 1 rats were treated with $3 \mathrm{mg} / \mathrm{kg}$ body weight of atropine sulphate (I.P), while Group 2 rats received $2 \mathrm{ml}$ of normal saline orally. Groups 3, 4 and 5 rats were given $250 \mathrm{mg} / \mathrm{kg}, 500 \mathrm{mg} / \mathrm{kg}$ and $750 \mathrm{mg} / \mathrm{kg}$ doses of the aqueous pods extract of Acacia nilotica orally respectively. After one hour, each rat was treated with $1 \mathrm{ml}$ of castor oil. One hour after the castor oil treatment, the rats were sacrificed and the small intestine removed, tied on both ends with thread and weighed, the intestinal content was collected by milking and the volume measured. The intestine thereafter was re-weighed and the difference between full and empty intestine calculated. 


\section{Effect of the aqueous extract on in vitro sensitivity testing}

The plates were aerobically incubated overnight at $37^{\circ} \mathrm{C}$ after which the individual plates were examined for zones of inhibition around the wells alongside the commercial disc preparations. The zone of inhibition present, were quantified by the direct linear measurement of their diameter (Cruishank, R. 1973; Carter, 1975; Chesbrough, 1975).

\section{Determination of minimum inhibitory concentration (MIC) of the aqueous pod extract.}

The method of Greenwood (1989) was used to determine the MIC of the aqueous pod extract of Acacia nilotica. Six sterile test tubes were arranged in a test tube rack and $0.5 \mathrm{ml}$ of each sterile nutrient broth pipetted in each tube. Half a millimetre of the crude extract containing 200 $\mathrm{mg} / \mathrm{ml}$ was pipetted into test tube one to obtain a concentration of $100 \mathrm{mg} / \mathrm{ml}$. Thereafter serial dilution of the extract to obtain concentrations of $50,25,12.5,6.25$ and $3.13 \mathrm{mg} / \mathrm{ml}$ respectively were done. The test organism $0.5 \mathrm{ml}$ and extract was pipetted into each of the test tube and incubated at $37^{\circ} \mathrm{C}$ for 24 hours. The MIC was recorded as the least concentration of pod extracts that completely inhibit the growth of the test organisms.

\section{Statistical analysis}

All values were expressed as Mean \pm Standard Deviation, while analysis of variance (ANOVA) was used to analyse the extent of variation between groups and $\mathrm{P}$ values equal to or less than 0.05 were considered significant (Mead and Curnow, 1982). Graphpad instat 3.0 for windows USA ${ }^{\circledR}$ computer software was used to analyse the data.

\section{RESULTS}

\section{Extraction}

The aqueous pod extract was light green and have slight bitter taste. The yield was $6.75 \%$ (w/w).

\section{Phytochemical Tests}

The result of the phytochemical analysis of the aqueous pod extract of $A$. nilotica is shown in (Table I). The result showed that the pod extract contained gallic tannins, flavone aglycone, pentoses, ketoses, reducing sugars, cardiac glycosides, alkaloids, saponins, and emodols.
Saponins and tannins occurred in very high concentrations, while alkaloids, flavone aglycone and reducing sugar occurred in moderate concentration and emodols, cardiac glycosides, pentoses and ketoses were found in low concentrations.

\section{Elemental analysis}

Potassium, sodium, zinc, manganese, cadmium, magnesium and iron were detected in the extract (Table I) of A. nilotica pod. Sodium had the highest concentration of $36.8 \mathrm{ppm}$. The concentrations of magnesium and iron were $0.85 \mathrm{ppm}$ and $0.55 \mathrm{ppm}$ respectively.

Table I. Phytochemical composition and Concentration of trace elements in A. nilotica pod powder

\begin{tabular}{llll}
\hline $\begin{array}{lll}\text { CHEMICAL } \\
\text { COMPONENT }\end{array}$ & $\begin{array}{l}\text { POD OF A. } \\
\text { NILOTICA }\end{array}$ & ELEMENTS & $\begin{array}{l}\text { CONCENTRATION } \\
\text { (PPM) }\end{array}$ \\
\hline Sterol and triterpenes & - & Calcium (Ca) & 0.00 \\
Emodols & + & Cupper(Cu) & 0.00 \\
Saponins & +++ & Lead(Pb) & 0.00 \\
Alkaloid & ++ & Arsenic(As) & 0.00 \\
Cardiac glycosides & + & Potassium(K) & 0.01 \\
Polyuronides & - & Manganese(Mn) & 0.02 \\
Reducing sugar & ++ & Zinc(Zn) & 0.07 \\
Phlabotannins & - & Cadmium(Cd) & 0.10 \\
Cyanogenic glycosides & - & Iron(Fe) & 0.55 \\
Anthracenosides & - & Magnesium(Mg) & 0.85 \\
Pentoses & + & Sodium(Na) & 36.80 \\
Ketoses & + & & \\
Anthraqinone derivatives & - & & \\
Gallic tannins & +++ & & \\
Catechol tannins & - & & \\
Flavone aglycone & ++ & & \\
\hline
\end{tabular}

WHO Standard Concentration (WHO, 1996)

$(-)=$ absence

$(+)=$ slightly present

$(++)=$ moderately present

$(+++)=$ copiously present

\section{The effect of aqueous pod extract of}

A.nilotica on castor oil induced diarrhoea

The result of the effect of the extract on castor oil induced diarrhoea is shown (Table II), aqueous extract of the pod of $A$. nilotica $(250-750 \mathrm{mg} / \mathrm{kg}$ per os) and diphenoxylate $3 \mathrm{mg} / \mathrm{kg}$ body weight, significantly $(\mathrm{P}<0.05)$ protected rats against castor oil induced diarrhoea in dose dependent manner when compared with the control group. The extract and diphenoxylate provided 41.4697.56 percent protection to the animals against diarrhoea induced by castor oil. The maximal effect of the extract was similar to that of diphenoxylate. 
The effect of aqueous pod extract on castor oil induced enteropooling

The result of the effect of $A$. nilotica aqueous pod extract on castor oil induced enteropooling in rats is presented in Table III. There was no significant difference $(\mathrm{P}>0.05)$ in fluid accumulated in the intestine of the rats in the control group and the group treated with the extract at $250 \mathrm{mg} / \mathrm{kg}$ body weight. Treatments with 500 and $750 \mathrm{mg} / \mathrm{kg}$ body weight of extract and atropine $(3 \mathrm{mg} / \mathrm{kg})$ significantly $(\mathrm{P}<0.05)$ decreased the accumulated fluid when compared with the control group. Atropine was observed to be superior to the extract in decreasing the intestinal fluid contents.

\section{The effect of aqueous pod extract on gastro intestinal transit of activated charcoal.}

The distance travelled by the charcoal meal in the control in comparison to the entire length of the small intestine from the pyloric sphincter to the ileocaecum was used as index of gastrointestinal motility in rats. The aqueous pod extract of A. nilotica $(250-750 \mathrm{mg} / \mathrm{kg}$ ) given orally significantly $(\mathrm{P}<0.05)$ reduced the gastrointestinal distance travelled by the charcoal meal in rats compared with control group (Table IV). The extract produced a dose dependent decrease of gastrointestinal transit in rats. The gastrointestinal transit of charcoal meal produced by atropine $(3 \mathrm{mg} / \mathrm{kg}$ ) was similar to that of $750 \mathrm{mg} / \mathrm{kg}$ of $A$. nilotica extract.

Table II. Effect of aqueous pod extract of Acacia nilotica on castor oil induced diarrhoea in wistar albino rats

\begin{tabular}{l|c|l|l}
\hline Treatment (mg/kg) & No. of rats & $\begin{array}{l}\text { Mean no. of } \\
\text { unformed } \\
\text { faeces }\end{array}$ & $\begin{array}{l}\text { Percent protection } \\
(\%)\end{array}$ \\
\hline $\begin{array}{l}\text { Control (CO + Normal } \\
\text { saline) }\end{array}$ & 5 & $8.20 \pm 4.27$ & 0.000 \\
\hline $250 \mathrm{mg} / \mathrm{kg}+C 0$ & 5 & $4.80 \pm 2.49^{*}$ & 41.46 \\
\hline $500 \mathrm{mg} / \mathrm{kg}+\mathrm{CO}$ & 5 & $0.80 \pm 1.09^{*}$ & 90.20 \\
\hline $750 \mathrm{mg} / \mathrm{kg}+C 0$ & 5 & $0.40 \pm 0.89^{*}$ & 95.12 \\
\hline $\begin{array}{l}\text { Diphenoxylate }(3 \mathrm{mg} / \mathrm{kg}) \\
+ \text { CO }\end{array}$ & 5 & $0.20 \pm 0.44^{*}$ & 97.56 \\
\hline
\end{tabular}

$\mathrm{CO}=$ Castor oil

P0.05 means significantly different from the control $b=$ Mean Standard deviation based on five observations
Table III. Effect of aqueous pod extract of Acacia nilotica on castor oil induced enteropooling in wistar albino rats

\begin{tabular}{l|l|l|l|l}
\hline $\begin{array}{l}\text { Extract treatment } \\
(\mathrm{mg} / \mathrm{kg})\end{array}$ & $\begin{array}{l}\text { Wt. of } \\
\text { intestine } \\
+ \text { content } \\
\text { (gram) }\end{array}$ & $\begin{array}{l}\text { Wt. of empty } \\
\text { intestine(gram) }\end{array}$ & $\begin{array}{l}\text { weight of } \\
\text { accumulated } \\
\text { fluid (gram) }\end{array}$ & $\begin{array}{l}\text { \% of fluid } \\
\text { accumulation }\end{array}$ \\
\hline Control & $8.00 \pm 1.50$ & $4.88 \pm 1.00$ & $4.06 \pm 0.59$ & $50.75 \%$ \\
250 & $9.14 \pm 2.14$ & $4.66 \pm 0.76$ & $3.48 \pm 1.45$ & $38.07 \%$ \\
500 & $7.86 \pm 1.99$ & $3.88 \pm 0.55$ & $2.48 \pm 1.21^{*}$ & $31.55 \%$ \\
750 & $5.60 \pm 1.28$ & $3.96 \pm 0.64$ & $1.64 \pm 0.68^{*}$ & $29.28 \%$ \\
Atropine $(3 \mathrm{mg} / \mathrm{kg})$ & $3.70 \pm 0.47$ & $3.12 \pm 0.30$ & $0.58 \pm 0.3^{*}$ & $15.67 \%$ \\
\hline
\end{tabular}

$\mathrm{CO}=$ Castor oil

P0.05 means significantly different from the control

$b=$ Mean Standard deviation based on five observations

Table IV. Effect of the aqueous pod extract of Acacia nilotica on mean gastrointestinal transit of activated charcoal in rats

\begin{tabular}{l|l|l|l}
\hline Treatment & $\begin{array}{l}\text { Total length of } \\
\text { the intestine }(\mathrm{cm})\end{array}$ & $\begin{array}{l}\text { Total movement } \\
\text { of charcoal }(\mathrm{cm})\end{array}$ & $\begin{array}{l}\text { Percentage(\%)distance } \\
\text { travelled by activated } \\
\text { charcoal }\end{array}$ \\
\hline Distilled $\mathrm{H}_{2} \mathrm{O}$ & $108.70 \pm 16.82$ & $80.00 \pm 13.6$ & 73.59 \\
Atropine & $106.80 \pm 11.24$ & $41.86 \pm 6.95^{*}$ & 39.19 \\
SO $(3 \mathrm{mg} / \mathrm{kg})$ & $127.10 \pm 9.90$ & $64.20 \pm 4.03^{*}$ & 50.50 \\
Extract $250 \mathrm{mg} / \mathrm{kg}$ & $113.80 \pm 3.05$ & $59.0 \pm 7.72^{*}$ & 47.36 \\
Extract $500 \mathrm{mg} / \mathrm{kg}$ & $117.70 \pm 10.76$ & $49.16 \pm 5.13^{*}$ & 41.77 \\
Extract $750 \mathrm{mg} / \mathrm{kg}$ & $11.70 \pm$ \\
\hline
\end{tabular}

P0.05 means significantly different from the control $b=$ Mean Standard deviation based on five observations

Table V. Zone of inhibition ( $\mathrm{mm}$ ) provided by the aqueous pod extract of $A$. nilotica on growth of some micro organisms

\begin{tabular}{|c|c|c|c|c|c|}
\hline \multirow[t]{2}{*}{ Organisms } & \multicolumn{4}{|c|}{ Extracts concentration $(\mathrm{mg} / \mathrm{ml})$. } & \multirow{2}{*}{$\begin{array}{l}\text { Tetracycline } \\
25 \mathrm{mg} \text { (control) }\end{array}$} \\
\hline & 700 & 400 & 200 & 100 & \\
\hline $\begin{array}{l}\text { Salmonella } \\
\text { typhi (mm) }\end{array}$ & 12 & 11 & 10 & 8 & 15 \\
\hline $\begin{array}{l}\text { Shigella } \\
\text { dysentery (mm) }\end{array}$ & 17 & 17 & 15 & 14 & 30 \\
\hline $\begin{array}{l}\text { Escherichia } \\
\text { coli (mm) }\end{array}$ & 10 & 8 & 7 & 6 & 20 \\
\hline P. aerogenosa (mm) & 12 & 11 & 10 & 8 & 13 \\
\hline $\begin{array}{l}\text { Staph. } \\
\text { aureus (mm) }\end{array}$ & 18 & 17 & 15 & 12 & 22 \\
\hline $\begin{array}{l}\text { Strep. } \\
\text { Pyogenus (mm) }\end{array}$ & 12 & 12 & 11 & 10 & 16 \\
\hline P. vulgaris $(\mathrm{mm})$ & 12 & 11 & 10 & 9 & 20 \\
\hline $\begin{array}{l}\text { Bacillus } \\
\text { albus (mm) }\end{array}$ & 17 & 16 & 14 & 12 & 26 \\
\hline C. albican (mm) & 17 & 15 & 14 & 14 & 30 \\
\hline
\end{tabular}

KEY:

Disc measurement $=0.6 \mathrm{~cm}$

Inoculation Temp. $=37^{\circ} \mathrm{C}$

Duration of inoculation $=24 \mathrm{hrs}$

Organisms used $=\mathrm{Lab}$. Isolates

Control Drug = Tetracycline $25 \mathrm{mg}$. 
Table VI. Minimum inhibitory concentration of the aqueous pod extract of $A$. nilotica

\begin{tabular}{l|l|l|l|l|l|l}
\hline \multirow{2}{*}{ Organisms } & \multicolumn{3}{|c}{ (mg/ml). } & \multicolumn{2}{c}{ Extracts } & \multicolumn{2}{c}{ concentration } \\
\cline { 2 - 7 } & 100 & 50 & 25 & 12.5 & 6.25 & 3.12 \\
\hline Staph. aureus & $\mathrm{S}$ & $\mathrm{S}$ & $\mathrm{S}$ & $\mathrm{R}$ & $\mathrm{R}$ & $\mathrm{R}$ \\
\hline Strepto. pyogenus & $\mathrm{S}$ & $\mathrm{S}$ & $\mathrm{S}$ & $\mathrm{R}$ & $\mathrm{R}$ & $\mathrm{R}$ \\
\hline Salmonella typhi & $\mathrm{S}$ & $\mathrm{S}$ & $\mathrm{S}$ & $\mathrm{R}$ & $\mathrm{R}$ & $\mathrm{R}$ \\
\hline Shigella dysentery & $\mathrm{S}$ & $\mathrm{S}$ & $\mathrm{S}$ & $\mathrm{R}$ & $\mathrm{R}$ & $\mathrm{R}$ \\
\hline P. aergenosa & $\mathrm{S}$ & $\mathrm{S}$ & $\mathrm{S}$ & $\mathrm{R}$ & $\mathrm{R}$ & $\mathrm{R}$ \\
\hline Escherichia coli & $\mathrm{S}$ & $\mathrm{R}$ & $\mathrm{R}$ & $\mathrm{R}$ & $\mathrm{R}$ & $\mathrm{R}$ \\
\hline Bacillus albus & $\mathrm{S}$ & $\mathrm{S}$ & $\mathrm{S}$ & $\mathrm{S}$ & $\mathrm{R}$ & $\mathrm{R}$ \\
\hline Candida albican & $\mathrm{S}$ & $\mathrm{S}$ & $\mathrm{S}$ & $\mathrm{R}$ & $\mathrm{R}$ & $\mathrm{R}$ \\
\hline
\end{tabular}

KEY:

$S=$ Sensitive

$\mathrm{R}=$ Resistance

\section{DISCUSSION}

The phytochemical test of the aqueous pod extract of $A$. nilotica indicated the presence of saponins and tannins in high concentration; alkaloids, reducing sugars and flavonoids occur in moderate concentration, while pentoses, ketosis, cardiac glycosides and emodols occur in low concentrations. It has been shown from scientific investigations that the potential use of extracts as therapeutic agents is due to the presence of active principles or chemical compounds in the extract (Abdulrahman, 2004). Antispasmodic and anti-diarrhoea effects of many medicinal plants have been attributed to their rich flavonoid and tannin contents (Abdullahi et al., 2001; Oyewole, 2003). The concentration of the essential and non- essential elements in the aqueous pod extract of $A$. nilotica, appears to be within the safety limit (WHO, 1996). The aqueous extract of $A$. nilotica was observed to reduce diarrhoea produced by castor oil. Castor oil is triglyceride of fatty acids. It contains ricinoleic acid, which when released induces irritation of the gastrointestinal mucosa, induces inflammation, cause increased fluid secretion and enhance motility of the gastrointestinal tract resulting in diarrhoea (Ammon et al., 1974). Since the extract has the ability to inhibit the castor oil induced diarrhoea, the mechanism of anti-diarrhoea effect exerted by the extract may include decreased gastrointestinal secretion and /or inhibition of gastrointestinal motility. Diphenoxylate (Standard drug) an opiate used in this study is known to inhibit gastrointestinal secretion and motility (Ammon et al., 1974). From this study, it is possible that the extract may mediate its effect through similar mechanism.

The extract was also observed to dose dependently prolonged the gastrointestinal transit period of activated charcoal. The passage of charcoal meal through the gastrointestinal tract in rats is used as a parameter to measure gastrointestinal motility and to study the laxative as well as the inhibition of intestinal motility (Abdullahi et al, 2001). The results of the study on the gastrointestinal transit revealed that the extract at $750 \mathrm{mg} / \mathrm{kg}$ reduced the distance travelled to $41.77 \%$, while Atropine $(3 \mathrm{mg} / \mathrm{kg}$ ) an antimuscarunic drug reduced the transit distance to $39.19 \%$. The extract was also observed to reduce the castor oil induced enteropooling. The ability of the extract to reduce the weight of intestinal content could be by preventing fluid and electrolyte secretion into the intestinal lumen and / or allow the content enough time to be exposed to the absorptive surfaces of the intestinal tract, (Gangarosa et al., 1960; Turnberg et al., 1970; Schulthesis, 1998).

Some flavonoids are known to have antimicrobial properties. The inhibition of the growth of Staphylococcus epidermidis, Streptococcus viridans, and Escherichia coli was reported by Okerulu, and Chinwe, (2001) to be due to flavonoids. Ogundipe et al. (1998) reported that flavonoids, tannins and saponins have inhibitory effect on the growth of Bacillus subtilis, E. coli, S. aureus and Candida albicans. Flavonoids present in the extract of $A$. nilotica used in this study have been demonstrated to inhibit contraction induced by spasmogens (Haruna and Choudhury, 1997; Abdullahi et al., 2001). The ability of the extract to inhibit gastrointestinal transit in rats suggests that the pod of this plant possess antispasmodic agents. Properties such as this (inhibition of contraction) may be responsible for the anti-diarrhoeic effect of the water extract of this plant. The results provide some justification for the use of this plant as natural anti-diarrhoeic agents and as well as remedy against colic.

\section{CONCLUSION}

The extract was found to have anti-diarrhoeic effect, since it inhibit castor oil induced diarrhoea, decreased the gastrointestinal transit 
time and reduced enteropooling. It also inhibits the growth of some bacterial and fungal organism that causes diarrhoea.

\section{ACKNOWLEGMENTS}

We thank Dr. U.S Hassan, Mr. Tanko Usman, Bitrus Wampana, Mal. Isa Gulani and Ibrahim Wiam for their technical assistance.

\section{REFERENCES}

ABDULLAHI, A.L., AGBO, M.O., GAMANIAL, K.S. AND WAMBEBE, C. (2001): Anti-diarrhea activity of the aqueous extract of Terminalia avicenniodes Root. Phytotherapy Research, 19:431-434.

ABDULRAHMAN, F.I., (2004): Studies on the chemical contents and Pharmacological Activities of the root bark extract of Vitex doniana (Black Plum). PhD Thesis Department of Chemistry University of Maiduguri.

AMMON, H.V. THOMAS, P.J. AND PHILIPS, S. (1974): Effect of Oleic and Ricinoleic acid on rat jejunal water and electrolyte movement. Journal of Clinical investigations 54:374-379.

BHATIA, S. C. (2005): Enviromental Pollution and Control in Chemical Processes Industries Khanna Publishers 2B Nath Market, Nai Sarak Delhi. 110006 772-802; 808-831

CARTER, G.R (1975): Diagnostic Procedure in Veterinary Microbiology. $2^{\text {nd }}$ ed. Springfield, Illinois, U.S.A 260-271.

CHESBROUGH, M. (1975): Medical Laboratory Manual for Tropical Countries. Vol. II. Tropical Health Technique. Butterworth's and Co. L.t.d, Kent, England. 198-204.

CHITME, H.R. CHANDA, B. AND KAUSHRK, S. (2004): Studies on the anti-diarrhea of Calotropis gigantean. V.br. in Experimental animals. J. Pharm. Pharmaceuticals Science. 7:70-75.

COUNCIL FOR INTERNATIONAL ORGANIZATION OF MEDICAL SCIENCES (C.I.O.M.O), (1985): International Guiding Principles for Biomedical Research Involving Animals WHO 1211, Geneva 27, Switzerland.

CRUICSHANK, R. (1973): Medical Microbiology. A Guide to the Laboratory Diagnostic and Control of Infection. $12^{\text {th }}$ ed. Vol. I. Churchille Livingstone, London. 601612.

DUKE J. A (1983): Antibiotic sensitivity testing in Microbial Chemotherapy (Greenwood, D. ed), Oxford University Press, New York 91-100.

GANGAROSA, E.J., BEISEL, W.R., BENYAJATIC, C., SRINZ, H.; PIYARATAN, P. (1960): The Nature in Asiatic cholera and its Relation to Pathogenesis: A Biopsy Study. American journal of Tropical Medicine Hygiene. 9:125-135.

GREENWOOD, D. (1989): Antibiotic sensitive testing. In: Antimicrobial Chemotherapy Greenwood. D. ed.), Oxford University Press, New York. 91-100.

HARBORNE, J.B. (1975): Phytochemical Methods. A Guide to Modern Techniques of Plant Analysis. Chapman and Hall, London. 279.

HARUNA, A.K. AND CHOUDHURY, M.K. (1997): Antispasmodic properties of the aqueous extract of Aristolochia albida. Dutch Phytotherapy Research, 2:527-528.

IOAN C. (1976): Practical Manual on the Industrial Utilization of Medicinal and Aromatic plants, Methodology for analysis of Vegetables drugs. UNIDO, Romania 128-141.

MASCOLO, N.A., CAPASSAN, R GERMANO M. P AND CAPASSO F. (1999): Inhibiting effect of cannabonoid agents on gastric emptying in the rat. Arrchives of Pharmacology, 360: $321-223$

MEAD, R. AND CURNOW, R.N. (1982): A simple Experiment in Statistical Method in Agriculture Biology. Chapman Hall, London. 33-46.

NATIONAL ACADEMY OF SCIENCE, (NAS), (1980): Firewood Crops, Shrubs and Tree specie for Energy Production. National Academy of Sciences, Washington D.C.2-10.

OFFIAH V. N AND CHIKWENDU U. A (1999): Anti-diarrhea effects of ocimun gratissimum Lin extract in experimental animals J. Ethanophorm. 68 327-330.

OGUNDIPE, O.O.; MOODY, J.O. AND ODEOLA, H.A. (1998): Antimicrobial and Anti-inflammation activities of Alchornea laxifora extractives. In. Proceedings of $1^{\text {st }}$ International Worshop on Herbal Medicinal Products, Ibadan, Nigeria. Nov. 22-24, 1998. 53-55.

OKERULU, I.O. AND CHINWE, J.A. (2001): The phytochemical analysis and anti-microbial screening of extracts of Tetracarpidium conophorum. Journal of Chemical Society of Nigeria.

OYEWOLE, J.A.O. (2003): Evaluation of the Antiinflammatory Properties of Sclerocarya birrea (Anacardiaceae) stem-bark extract in rats. Journal of Ethnopharmacology, 85:217-220.

PANDE, M. B., TALPADA, P. M PEBEL J. S., AND SHUKLA P. C (1981): Note on the nutritive value of babul (Acacia nilotica Linn) Seeds (extracted) In: Indian J. Ani. Sci. 51 (1): $107-108$.

ROBERTS, A. NEIZAMIS, J. E LANCASTER C, HANCHAR A. J KLEPPER, M.S. (1976): Enteropooling assay a test for diarrhea produced by prostaglandins, 11: 809-828

SCHULTHESIS, P.J. (1998): Renal and Intestinal Absorptive Defects in Mice Lacking the NHE3 $\mathrm{Na}^{+} / \mathrm{H}^{+}$Exchanger. Nat. Genet. 19:282-285.

SOFOWORA, E.A. (1993): Recent Trends in Research into African Medicinal plants. J. Ethnopharmacol. 38: 209214.

TREASE G. E AND EVANS, M. D (1989): A Textbook of pharmacognosy, 13th ed. Baillier, Tindal and Causee London, 144-148, 687-689.

TURNBERG, L.A.; FORDTAN, J.S.; Carter, N.W.; Rector, F.C.Jr. (1970): Mechanism of Bicarbonate Absorption and its Relationship to Sodium Transport in the Human Jejunum. J. Clin. Invest. 49:548-556.

WHO (1996): Guideline for Elemental Concentration, trace elements in Health and Human Nutrition.50-228. 